\title{
THE EARLY YEARS: THE QUEST FOR A FREE SPACE IN A RESTRICTED ENVIRONMENT
}

\author{
Bernard Lategan \\ Department of Information Science \\ Stellenbosch University
}

\section{Abstract}

This article discusses the considerations which led to the establishment of Scriptura in 1980. Against the backdrop of a looming social and political transformation, the intellectual, political and ecclesial climate was restrictive in many ways and on various levels. The strict adherence to disciplinary boundaries in academe, the dominant political ideology of oppression and exclusion, and the inertia caused by hierarchical systems of ecclesial control all contributed to the need to find spaces where alternative approaches could be explored and tested. In the process, fortunate co-incidences or instances of serendipity played an important role. The intention of this article is neither to provide a historical account of these developments nor an overview of the contents of the journal, but rather to explore the forces which influenced the course of events, often behind the scenes and on a meta-level. After the first decade, the journal was established enough to pursue more conventional objectives.

Keywords: Scriptura; Academic journals; Biblical scholarship; Disciplinary isolation; Ecclesial control; Socio-political transformation

\section{Introduction}

Journals, like people, are children of their time. Scriptura is no exception. The intention of this article, which focuses on the first decade $(1980-1990)$, is neither to provide a historical account nor an overview of its contents, but rather to sketch the denkklimaat (intellectual climate) and tydsgewrig (epoch - terms very much in vogue at the time) in which the journal came into being. In the forefront were several immediate needs and practical reasons for its establishment. The editorial of the first issue (July 1980) offers an extensive rationale for launching yet another publication in an already crowded field. I shall return to some of these arguments in due course.

However, the wider background of these more immediate concerns was the ominous rumblings of a society on the verge of a fundamental and comprehensive social and political transformation that would affect every aspect of life. Although the eighties were the high point of the apartheid state and of the power of the governing National Party, it was equally clear that this dispensation was nearing its end. In the circles of the "struggle", the coming liberation was eagerly and enthusiastically anticipated, while in the camp of the government and its supporters it was awaited with growing fear. Tensions ran high, fed by contrasting emotions of hope and despondency, of longing for a new dawn and of trepidation at the loss of privilege and power - and the violence and chaos that was presumed to follow. International sanctions against the country became more stringent and internal insurgence escalated. A partial state of emergency was 
declared in 1985, and it became nation-wide in 1988. Forty years down the line, it is difficult to re-imagine this situation of a society at war with itself, in a state of physical and psychological danger, characterised by an all-pervasive sense of uncertainty. ${ }^{1}$

The turmoil on the political front was the most visible manifestation of a much wider realisation that an era was coming to its end. This Zeitgeist permeated all spheres of life - music, art, literature, lifestyle, and even the distant and dusty halls of academe. Change was in the air. Time-honoured dogmas and the pillars supporting the status quo came under critical scrutiny. A willingness - even urgency - to abandon current paradigms energised an unprecedented quest for alternatives.

This formed the existential context in which Scriptura first saw the light. Although it was - as an academic enterprise - far removed from the actual sites of struggle, it was nonetheless affected by them in direct and indirect ways. This relates to both the forces of change and the forces resisting change. The latter consisted mainly of attempts of physical and mental control, using force or other strategies of containment, thought policing and intimidation, which resulted in a highly restrictive environment in which borders, limits, laws and rules featured prominently. To explain its peculiar setting, more needs to be said about the "social location" of the journal.

\section{Social location}

The journal had a hesitant beginning, characterised not only by the usual trepidations of such an undertaking, but also by the awareness that it was entering unchartered territory. Because its long-term sustainability was all but assured, each issue was published as a separate volume (see the volume numbers). The first issues (in ungainly A4-format) were manually clamped into plastic binders - a far cry from the professional appearance of the print and online issues of today.

The initial social location of the journal had a physical as well as an intellectual dimension. Its physical address was the Department of Biblical Studies at Stellenbosch University, but intellectually it was linked to departments which were not directly involved in preparing students for the ministry (UWC, Unisa, UPE). There hangs a tale: at the time, Biblical Studies did not have the same standing as disciplines like New or Old Testament, which formed a substantial part of the curriculum of theological students training for the ministry ${ }^{2}$. It was primarily a "school subject," popular among education students preparing for a teaching career. It did not require knowledge of Hebrew or Greek (except in certain cases, at a post-graduate level) and was consequently not taken as

To quote from the 2020 virtual exhibition of SAHA (the South African Historical Archive) to commemorate the End Conscription Campaign (http://www.saha.org.za/ecc25/ecc_under_a_state_of_emergency.htm consulted on 25.1.2020):

"By the mid-1980s, South Africa was in flames, with violent resistance and escalating insurgence from all borders, including the ones inside the country. Rural uprisings in the desiccated countryside of South Africa's Bantustan homelands were met by violent demonstrations within the sprawls of South Africa's peri-urban townships.

The state's response was to declare a state of emergency, something usually declared when the welfare of a nation is so threatened by "war, invasion, general insurection, disorder, natural disaster" that such a declaration is deemed "necessary to restore peace and order." It gave the President of South Africa the ability to rule by decree, to heighten the powers of both SADF and SAP, and to restrict and censor any reportage of political unrest. The constant state of low-level siege experienced throughout this decade was divided by two such 'declarations."'

2 Kinghorn, (1982:31) refers to the "para-theological” status of Biblical Studies at the time. 
seriously as other theological subjects. From the perspective of church authorities and university management, the actual placement of the subject and in a department posed a dilemma. In some cases, it was housed in the Faculty of Arts or Humanities (SU, UWC, UPE). In other cases, it became part of the Faculty of Theology (UP, Unisa, PU for CHE).

The establishment of the Department of Biblical Studies at Stellenbosch was a prime example of what Nettelbeck (2019) calls "serendipity" - one of those fortunate, unintended coincidences which opened unforeseen possibilities. Its founding was not based on any pressing academic or intellectual reasons, but was in fact the by-product of a staff reshuffle in the Department of Semitic Languages. The outcome was that it remained in the Faculty of Arts and Social Sciences. In due course, it became a flourishing department with large numbers, mainly students preparing for a teaching career.

As an initial home for Scriptura, this specific social location had both advantages and disadvantages, as will soon become apparent. One disadvantage was that the Department was not that influential, neither in the Faculty of Arts and Social Sciences nor in the Faculty of Theology. On the other hand, being free from ecclesial supervision and a bit under the radar, there was more space for experimentation and the exploring of alternative approaches.

The first editorial (Scriptura (1980 (1):1-6)) sets out the parameters of the proposed journal: The target readers are students preparing for a teaching career and teachers in need of further in-service training; scholarly rigour will be the over-all norm; research will be conducted in dynamic interaction with other (secular) disciplines in the humanities and further afield and will be informed by the socio-political challenges of the day; the journal intends to provide a publication platform for the latest research; expository articles, wherein "illustrative exegetical procedures" will form an important component; an inclusive approach will be followed to enable the co-operation of a wide as possible spectrum of colleagues and universities. ${ }^{3}$

These "surface goals" were signifiers of a less visible "hidden transcript" and part of a strategy to prepare the ground for a bolder objective: To circumvent the restrictions inherent in the situation described above and to actively pursue alternatives to the status quo. The predominance of students following the subject for general or teaching purposes (in contrast to students preparing for the ministry) meant less ecclesial scrutiny and more space to experiment. The emphasis on scholarly rigour and on the latest research signalled the commitment to intellectual integrity and intended to counter the mistaken impression of pietism which is often associated with Biblical Studies. The inclusive approach was meant to expand the circle of students and scholars participating in the conversation. The reference to "our troubled society" and its "difficult problems" was an acknowledgement that socio-political realities could no longer be ignored. The basic hermeneutical orientation of the journal was underlined by the emphasis on "interpretive procedures" and the fact that the opening article by Rossouw (1980) was a

Compare this to the self-description of the Journal in 2020: "Scriptura is an independent journal which publishes contributions in the fields of Bible, Religion and Theology refereed by peers. It is international in scope but special attention is given to topics and issues emerging from or relevant to Southern Africa. Scriptura publishes contributions in English but also in other languages relevant to the Southern African region (such as Afrikaans, Xhosa, Sesotho, Zulu, French and German)”. 
programmatic statement of the "hermeneutical problem" to be followed by a hermeneutical analysis not of a Biblical text, but of Brahms' selection of scripture passages for his Deutsches Requiem (Lategan, 1980). But perhaps most significant was the insistence that students of Biblical Studies give account of themselves in an academic world which they share "with students in the sciences and the humanities. Biblical Studies cannot be studied in isolation, but only in dynamic interaction with other fields of science". The horizon of the discourse in which students of Biblical Studies would immerse themselves would not be constituted by the boundaries of neighbouring theological disciplines, but encompass academe in toto.

Right from the start, the journal thus has had a two-fold agenda. On the first level, it pursued customary academic goals, attempting to carve a distinctive niche for itself in the already crowded world of academic publishing. On a second level, it was intent on exploring - more tentatively or more boldly - alternative approaches to the one which it experienced as a stifling and constrictive environment. At stake were constraints of a diverse nature, operating on different levels. Not all of them were the exclusive product of the Zeitgeist of the eighties. Nonetheless, the tensions and uncertainties of the time increased their intensity and made it that more urgent to break the stranglehold of these constraints.

\section{Academic constraints}

South African universities did not escape the general turmoil which engulfed the country at the time, but as institutions of higher learning they faced a unique set of challenges. The disruption of academic programmes, international isolation (including academic boycotts), protest movements and clashes with security forces which turned some campuses into sites of struggle - all of this contributed to a highly unstable environment. However, there were also uniquely intellectual constraints at play which were not the direct result of the current situation, but which had a longer history with implications for the intellectual agenda Scriptura was pursuing.

The most important of these was a growing disciplinary isolation and disengagement from the encyclopaedia of knowledge or "academic universe". Disciplinary specialisation, no doubt, contributed greatly to the rapid growth of knowledge, but during the eighties this trend began to develop negative tendencies.

A prime example is the curriculum for students intending to enter the ministry. ${ }^{4}$ Previously theology students had a thorough preparatory training in the humanities, consisting of a bachelor degree with a minimum of two years of Hebrew and Greek. Many of these students continued with post-graduate study in subjects like philosophy, Semitic and classical languages, psychology, or history, thereby enriching and broadening not only their own development, but that of theology itself.

By the second half of the previous century the tide began to turn. For a variety of reasons, including cutting the high cost of university education, the goal became to shorten and streamline courses by eliminating all components which were considered to be "non-essential". The practical outcome was that broad-based education fell by the

The relationship between church and higher learning, between seminary and university (including the issue whether theology belongs at the university in the first place) form part of a centuries-old debate which cannot be discussed here in any detail. 
wayside. The physical outlay of campuses, which did not encourage inter-disciplinary contact, also played a role. One could complete one's whole degree without any serious interaction with students from a different faculty or discipline. Not only theology, but also medicine, engineering, law and other professions suffered from this isolation.

Added to this general pedagogical attenuation was a certain "internal" contraction of Biblical Studies itself, namely the expectation that the subject should restrict itself to the "background" of the Bible, namely its historical, archaeological, and geographical setting and to the history of the text and its transmission. This expectation - based on what Kinghorn (1982:32) calls a "naïve hermeneutics" - disregards the integrative nature of the full cycle of interpretation, sense-making and application and can only lead to the trivialisation of the subject.

The situation was exacerbated by the policing of disciplinary boundaries which discouraged any cross-border incursions. In one instance, in the Faculty of Arts and Social Sciences at Stellenbosch, the appointment of a supervisor from Biblical Studies for a PhD student in Greek met with strong opposition. General linguistics was separated from Afrikaans linguistics, music from school music, maths from maths for engineers, psychology from educational or industrial psychology and so forth. Whatever advantages these sub-specialisations might have had in their specific context, they certainly did not encourage inter- and cross-disciplinary pollination.

Against this backdrop of intellectual contraction and the patrolling of disciplinary boundaries, the academic location of Biblical Studies - and per implication of Scriptura - suddenly became its most important asset. It is not by accident that the "founding" partners of the journal shared a similar position: Biblical Studies at UWC, UPE and later the Institute for the Study of the Bible at UKZN formed part of the Humanities and Social Sciences at their respective universities. At Unisa, Biblical Studies was housed in the (non-denominational) Faculty of Theology, but Willem Vorster's Institute for Theological Research from the outset had an inter-disciplinary and ecumenical character.

Consequently, the reality on the ground was that colleagues in Biblical Studies worked in constant dialogue with a wide spectrum of "non-theological" disciplines, rubbing shoulders on a daily basis with their counterparts from political science, sociology, philosophy, history, journalism, performing and visual arts, and the like often sharing the same building or tea-room and being exposed to a wide variety of methodological traditions and scientific paradigms. Even more importantly, they found themselves in a secular environment where their subject had no privileged or sacrosanct status. They had to fend for themselves on an equal footing where the quality of their insights and their arguments was the only currency. The loss of influence in theological circles was thus compensated by a robust and creative interaction with secular subjects. This had a profound effect on the nature of the discourse which ensued and which also influenced the style of the journal which started to promote the widest possible interdisciplinary participation. Kinghorn's article on Biblical Studies as "theology in the market place" (Kinghorn 1982) and Deist's discussion of the task of Biblical Studies in a secularised world (Deist 1990) were some of the earliest ventures into what later became known as "public theology".

There was also another reason why Biblical Studies and Scriptura were more at home in the humanities, namely the deep cultural-historical impact which the Biblical tradition 
had on so many aspects of human life, such as literature, art, architecture, philosophy, history, education, law, music, ethics, war and peace (Kinghorn 1982:35).

Right from the start Scriptura published articles from a wide range of disciplines. Apart from contributions from other theological fields like systematic theology, practical theology and theological ethics, the first decade saw work from disciplines like philosophy, psychology, musicology, education, value studies, political science, psychology, linguistics and hermeneutics.

At the same time it must be conceded that these "non-theological" or "secular" articles seem to be collected in an unsystematic and almost random way, giving the journal a certain rogue appearance. There is little evidence at this stage of a sustained dialogue between disciplines where methodologies and bodies of knowledge engage with one another. It is almost if the ice had first to be broken before substantial interdisciplinary interaction became possible. This did follow later - not necessarily on the pages of Scriptura, but in the wider university environment. Here, a gradual mindshift was taking place, loosening the confines of a strict mono-disciplinary approach and based on a growing realisation of the deeply-interrelated nature of knowledge - what Nyamnjoh (2015) would later call the "incompleteness" of knowledge as part of his plea for "convivial scholarship". One example was the emergence of interdisciplinary academic courses in the nineties when universities were required to review and restructure their whole academic offering. Post-graduate master courses became a popular vehicle to achieve this, where modules from different disciplines were added to a bachelor degree, of which the $\mathrm{M}$ in value and policy studies, applied ethics, and international relations are examples. In some sense, this was the precursor of the kind of interdisciplinary research promoted by STIAS (the Stellenbosch Institute for Advanced Study).

\section{Ecclesial constraints}

The study of theology as part of the process of preparing candidates for the ministry is not purely an academic matter - a situation similar to other professions. As in engineering, medicine, or law, the "licence" to practice in the field is granted by a professional body which also has a say in the curriculum which is taught by universities. Each church or denomination has its own set of requirements for admission to the ministry. Some do not require formal academic qualifications but, where they do, this normally depends on an agreement between the specific church and a university (or number of universities). Regardless of how this relationship is structured in practice, the system of (additional) external control creates the possibility to impose certain restrictions on the content and method of academic teaching.

Although Scriptura was located in a department at the Faculty of Arts and Social Sciences at Stellenbosch, it had to contend with the presence of a Theological Faculty of the Dutch Reformed Church at Stellenbosch. The situation at the other "founding" universities was slightly different. UWC had a School (later Faculty) of Theology serving the then Dutch Reformed Mission Church, but Biblical Studies was part of the Arts Faculty where students were preparing for teaching careers or chose the subject as part of a general bachelor's degree. UPE had no Faculty of Theology and students aiming for the ministry had to complete their studies elsewhere. The Faculty at Unisa was non- 
denominational, but a number of churches and denominations made use of the courses it offered - a situation similar to the School of Theology at UKZN which followed later.

The constraints in the ecclesial domain functioned on two levels: control exercised by church authorities and the limitations imposed by the discipline itself in the way it approached its scientific task.

Admission to the ministry in the DRC, for example, was granted by the Curatorium (Board of Curators) through a formal process of "legitimation". This "licence" depended on a number of criteria like personal character, ability, academic qualifications, and adherence to the doctrine of the church. The latter was by far the most important and used very effectively as shibboleth to prevent questionable individuals (in the opinion of the church authorities) to participate in the training of students for the ministry. But, in addition to these confessional criteria (cf. Kinghorn 1982:32), there were also criteria like political correctness (that is, adherence to the policy of apartheid) at work. Examples range from the infamous Du Plessis heresy trial of 1930 to the withdrawal of Jaap Durand's permission to preach in the DRC (cf. Lategan 2001; Die Burger 29/11/2019). The careful vetting of appointments to the Theological Faculty (candidates had to be approved by the church) was another form of control which was even extended to the pre-theological phase, as the well-known side-lining of Degenaar illustrates (cf. Van Niekerk 2017). These measures stifled free scientific enquiry, but they ironically also had an unintended effect. Research-minded students found other outlets to satisfy their intellectual curiosity and turned to post-graduate study in other disciplines - largely in philosophy but also in psychology, history, literature, and Semitic and classical languages (cf. Nash 1997b).

Students of Biblical Studies preparing for teaching or "secular" careers were not subjected to these ecclesial controls. The same applied to Scriptura as an academic journal. Under the auspices of the Faculty of Arts, it was not only slightly under the ecclesial radar, but also more free to experiment with alternative approaches which moved beyond the strict doctrinal or confessional boundaries of a given denomination.

Did the journal make full use of these opportunities? As will be explained below, the issues of the first decade present a mixed picture. The fact was that the relevant academic disciplines, and more specifically Old and New Testament studies and Education, were to a large measure (quite apart from external constraints) also caught up in their own isolation, following the guidelines of their respective guilds for what qualifies as scientific research. In the Bibliological subjects, for example, the fixation on the text and its internal relationships reinforced an a-historical approach. Exegetical analyses and articles on the teaching of Biblical Studies at school show little methodological innovation or evidence of a critical consciousness.

It was only with the decisive shift of focus away from "inception" to "reception", that is, from the conditions of text production to the realities and implications of text reception and the deliberate inclusion of the full spiral of communication in both theoretical reflection and in pursuing its practical implications, that new impulses were released. The establishment of the Centre for Contextual Hermeneutics played an important role in this regard. Scriptura became the regular outlet for the research and discussions at the annual meetings of the Centre (see for example Scriptura S9 (1991)).

The acknowledgement of the critical role of contextuality made it possible to integrate different aspects of the hermeneutical process in a holistic way (Lategan 1991). 
The historical dimension (that is, the singular original context of communication) could thus be connected via the mediating and preserving structural dimension of the text with the multiple contexts of reception. This theoretical extension enabled the inclusion of a spectrum of readers (implied, unintended, 'ordinary' and the like), as well as a variety of readings (resisting or affirming; or from a black, liberation, gender, minority or power perspective). At the same time, it provided the theoretical basis for the inclusion of readings from other disciplines, that is, readings in different settings and for different purposes. For example, the contributions of Van Huyssteen 1981, De Gruchy 1981, De Villiers 1983, Esterhuyse 1986, Jüngel 1988, Kinghorn 1988, Sebothoma 1989, and Smit 1990, 1999 illustrate the increasing scope of the journal. At the same time it signalled the beginning of a shift away from fixated paradigms and the undermining of the status quo.

\section{Socio-political constraints}

In what way was the journal constrained by the socio-political situation? Like any academic journal worth its salt, scholarly rigour; critical, unbiased analysis; and intellectual integrity were important values if Scriptura was to earn the respect of its peers and to be accepted by the world of academic publishing. As we have seen, these values were explicitly articulated in the editorial of the first issue.

The right balance between engaged scholarship and academic distance is an issue with which most disciplines and publications in the social sciences have to grapple. There is the constant possibility that academe becomes directly involved in the "subject matter" it studies, especially in a highly charged political atmosphere. Nyamnjoh has recently argued that certain strands of engaged social anthropology run the risk of becoming an "evangelising public anthropology" if they forsake their rigorous commitment to science, theory building and an acknowledgement of associated epistemologies. He consequently calls for a commitment to "the essential task of producing critical knowledge of critical value, and to re-embrace and fulfil anthropology's core mission and ambition as an evidence-based field science" (Nyamnjoh 2015:48).

In the case of Scripura, the socio-political context did not act as a constraint on the ambitions of the journal to maintain a rigorous academic profile. Its effect was more indirect, but at the same time all the more pervasive. Omni-present was a gnawing awareness that the political dispensation was fundamentally unjust, discriminatory, divisive, suppressive, and undemocratic. What made it especially acute in the case of Biblical Studies was that the moral justification of the system was based on the very subject matter of the discipline, namely Biblical Texts. This placed a heavy onus on this core subject. During the eighties, the condemnation of apartheid and its purported Biblical justification was gaining momentum, locally and internationally, mostly outside, but also inside the church - including isolated voices in the DRC.

Denouncing an unjust system and exposing the roots of its ideology was just the first step. What was more urgently needed, was the articulation of an alternative dispensation which was morally sound (cf. Kinghorn 1986:192). Finding alternatives was (as we saw) one of the "hidden" ambitions of Scriptura. It is in this regard that Biblical Studies was hampered by a serious constraint - ironically, one of its own making. 
- In his incisive analysis and sharp criticism of South African exegetical Biblical scholarship during the nineteen-eighties, Smit (1990:42) makes clear how ensconced the discipline still was in its ethos of institutionalised scientific scholarship, "safeguarding its practitioners from the aberrations and conflicts of both the socio-political and dogmatic struggles". Furthermore, most scholars from Afrikaner Reformed circles "could not rid themselves of the controls and the inherent constraints of the institutionalized ecclesial and spheres". When they did address issues of ecclesial conflict with socio-political overtones, they were hesitant and reserved, "almost apologetical of the mere fact that they write with a view to a specific present-day conflict" (1990:46).

Although Smit addresses his critique mainly to the scholarship of the New Testament Society of South Africa, his remarks also apply to many of the contributions published in Scriptura during its first decade. The same hesitancy and socio-political "detachment" are in evidence here, illustrating how the constraints under discussion also came from within the guild itself. At the same time, there were also early signs of a wider, more inclusive and integrative approach, of which the programmatic essay of Kinghorn (1982) is one example.

Here again, the broadening of the scope of the discipline and especially the inclusion of reception on both the theoretical and pragmatic level, started to change things. When not only the original audiences and the first readers of Biblical texts but also their present-day readers and their existential contexts became part of the equation, no part of the communication process could be excluded arbitrarily. For the same reason, a retreat to the historic-critical level and the confines of scientific scholarship is also not an enduring option. Vorster is correct in his contention that many of the critics of apartheid theology use exactly the same hermeneutical approach as its proponents (Smit 1990b:3135). Vorster consequently calls for strict adherence to the tenets of the historical-critical approach. But when he then proceeds to rely on individualistic, almost casuistic, decisions on an ad hoc basis, further questions arise, as Smit (1990b:36) makes clear: What does it mean to be "in line" with the Bible? How does "hope in Christ" or the "salvation of the Christian" function as an interpretive guideline? Could it be that the wisest course of action is to remove as far as possible the many constraints we have discussed and to allow the theological and rhetorical thrust of the text to run its own course?

As far as Scriptura is concerned, the situation also began to change towards the end of its first decade - slowly and tentatively at first and perhaps not so strongly influenced by Schüssler-Fiorenza or Wuellner as Smit (1990:29, 37, 42) would have wished. It was rather via reception that the door was openend for the influx from other perspectives and disciplines like contextual hermeneutics, liberation theology, gender studies and even ethics. One example of the latter is the special edition "Geloof en Opdrag" (Scriptura S9a) published in 1992 on initiative of Cilliers Breytenbach and in which ethical issues related to the South African situation formed the focal point.

By the end of the second decade, the journal was past its hesitant stage and fully engaged in ethical, socio-political and multi-religious issues in South Africa, across Africa and beyond (see for example the contributions of 1990 in volumes 68-71 of Scriptura). 
However, to return to the goal of moving beyond mere criticism of apartheid to propose - as stated above - an alternative dispensation that was morally sound, The Option for Inclusive Democracy (Lategan, Kinghorn, du Plessis and de Villiers: 1987) was a more substantive contribution in this direction. Although not published in Scriptura but by the Centre for Hermeneutics (soon to become the Centre for Contextual Hermeneutics) it came from the same department and by authors who were regular contributors to the journal.

The Option was unusual in several respects. The first part consisted of a discussion of fundamental theological-ethical values of special significance for "the structure of a future South Africa". These included values related to human equality, unity and interdependence, freedom, governance, social responsibility, and human rights. In the second part, these theological values are translated in" secular" terms in order to be accessible to religious and non-religious citizens alike. A list of unacceptable values is followed by a set of positive values which are then applied to the South African situation. Finally, an appendix of basic human rights is added, which is in reality a rudimentary draft of a bill of human rights intended to be included in a future constitution for the country.

The authors come from an Afrikaans Reformed background, but they make clear that the document is the product of a collaborative effort and ongoing consultation with fellow South Africans from various sectors of society. The initial impulse was the report of the HRSC's Investigation into Intergroup Relations (1985). One of its main findings was that there does exist a potential consensus of social values among South Africans which could contribute to the establishment of a more just society - a finding which was validated in their discussions with black compatriots and the latter's support of the same basic values. Thus a re-evaluation of the authors' own theological tradition "makes clear that the case for an inclusive democracy without an ethnic or racial basis can be argued more strongly and more convincingly from this very tradition" (The Option: iii).

\section{Conclusion}

Did Scriptura succeed in the goals it initially set for itself? If the question is whether the journal provided space to experiment and a platform to explore alternative approaches given its social location and the constraints of the time - the answer must be yes.

If the question is whether the journal itself changed things, the answer becomes more complicated. How is such a contribution (or lack thereof) to be measured in any case? Judgement in this matter is best left to others, who were not intimately involved in the establishment of the journal. What can be said of the first decade is that it remained work in progress. Much of the work is still hesitant, carefully formulated and apologetic in tone. Smit is correct that in many cases contributions remain within the confines of conventional Biblical scholarship, showing little or no awareness of wider ethical and social issues. On the other hand, there were also daring ventures into the unknown, exploring substantial questions beyond the limits of linguistic or historical concerns. The emphasis on the reader and contextual hermeneutics contributed largely to initiate this shift. In this sense the journal did pave the way for more momentous and substantial changes which were to follow later.

By 1990, many of the original constraints fell away or assumed different configurations. Inter-disciplinarity and the cross-pollination of ideas are currently prominent features of 
research in general as well as among theological disciplines ${ }^{5}$. Contextuality and hermeneutics have become mainstream, and the masthead of the journal now reads: "Journal for Biblical, theological and contextual hermeneutics". The fact that monodenominational training was largely replaced by multi-denominational teaching in multidenominational faculties meant that ecclesial control lost much of its former hold, although it remains in more subtle forms. The fact that the Department of Old and New Testament at Stellenbosch University was willing to take over Scriptura, when Biblical Studies morphed into Information Science and the journal was about to close, is evidence of its changed status - but it also injected much needed energy and signalled the beginning of a flourishing new lease on life. And presently, the journal has co-editors from Stellenbosch and UWC with an editorial board from all over the country and the continent. With the advent of an inclusive democracy, the socio-political landscape changed irrevocably but brought with it new ethical challenges, including continuing and even increasing levels of inequality, new forms of discrimination and exclusion, and environmental ethics. So, the task continues!

\section{BIBLIOGRAPHY}

Breytenbach, C. and Lategan, B.C. (eds.) 1992. Geloof en opdrag. Perspektiewe op die etiek van die Nuwe Testament, Scriptura S9a.

De Gruchy, J.W. 1981. Bonhoeffer's English Bible, Scriptura 3:9-18.

Deist, F.E. 1990. The hermeneutical of the sacred and the task of Biblical Studies in a secularized world, Scriptura 33:6-15.

Deist, F.E. 1994. Ervaring, rede en metode in Skrifuitleg. 'n Wetenskapshistoriese Skrifuitleg in die Ned. Geref Kerk 1840-1990. Pretoria: RGN.

De Villiers, E. 1983. Putting the recent debate on conscientious objection into perspective, Scriptura 8:21-33.

Esterhuyse, W.P. 1986. Die rol van waardes in die proses van konstitusionele hervorming, Scriptura 18:22-40.

Jüngel, E. 1988. Hat der christliche Glaube eine besondere Affinität zur Demokratie?, Scriptura 27:1-7.

Kinghorn, J. 1982. Bybelkunde: Teologie op die markplein, Scriptura 6:29-42.

Kinghorn, J. 1988. Twee teologies-etiese perspektiewe op ' $n$ keuse vir inklusiewe demokrasie in Suid-Afrika, Scriptura 27:8-19.

Kinghorn, J. (ed.) 1986. Die NG Kerk en Apartheid. Johannesburg: Macmillan. Lategan, B.C .1980. Ein Deutsches Requiem: Notes on Brahms' selection of Biblical texts, Scriptura 1:29-41.

A glance at Scriptura 115 (2016) reveals contributions from environmental issues, food and eating, African feminist pneumatology, film interpretation, gender studies, black theology, land reform, restoration theory, the biblical critic as a public intellectual, food symbolism and food security, biblical-ethical hermeneutics, African biblical hermeneutics, indigenous belief systems, Orthodox ecclesiology and exegetical methodology, religious liberty and the South African constitution, African philosophical analysis, Pentecostal theology, syncretism, hybridity and ambivalence, the NT as political documents, poverty reduction, land, farming and socio-economic development, leadership studies, feminist critique of educational models, parenting, Jesus' identity, and Ricoeur's concept of metaphor. 
Lategan, B. C. 1991. The challenge of contextuality, Scriptura S9:1-6.

Lategan, B. C. 2001. Preparing and keeping the mind-set intact. Reasons and forms of a theology of the status quo, Scriptura 76:63-75.

Lategan, B., Kinghorn, J., Du Plessis, L. and De Villiers, E. 1987. The option for inclusive democracy. A theological-ethical study of appropriate social values for South Africa. Stellenbosch: Centre for Hermeneutics.

Nash, A. 1997a. Wine-farming, heresy trials and the 'whole personality': the emergency inpof the Stellenbosch philosophical tradition, 1916-40, South African Journal for iL Philosophy 16:55-69.

Nash, A. 1997b. How Kierkegaard came to Stellenbosch: the transformation of the Stellenbosch philosophical tradition, 1947-50, South African Journal for Philosophy 16:129-139.

Nyamnjoh, F.B. 2015. Beyond an evangelizing public anthropology: science, theory and commitment, Journal of Contemporary African Studies 33(1):48-63. http://dx.doi.org/10.1080/02589001.2015.1021214.

Nyamnjoh, F.B. 2019. ICTs as Juju: African inspiration for understanding the compositeness of being human through digital technologies', Journal of African Media Studies, 11:3, pp. 279-291, doi: 10.1386/jams_00001_1.

Nettelbeck, J. 2019. Verwalten von Wissenschaft, eine Kunst. Berlin: Max Planck Institute for the History of Science.

Rossouw, H.W. 1980. Hoe moet mens die Bybel lees? Die hermeneutiese probleem, Scriptura 1:7-28.

Schüssler-Fiorenza, E. 1998. The ethics of interpretation: de-centering biblical scholarship, Journal of Biblical Literature 107:3-17.

Scriptura $S 9$ (1991). Issues in contextual hermeneutics.

Sebothoma, W. 1989. Contextualization: a paradigm-shift?, Scriptura 30:1-14.

Smit, D.J. 1990a. The ethics of interpretation - new voices from the USA, Scriptura 33:16-28.

Smit, D.J. 1990b. The ethics of interpretation - and South Africa, Scriptura 33:29-43.

Van Huyssteen, J.W.V. 1981. Opmerkings oor geloof en geloofsuitsprake, Scriptura 3:1-8.

Van Niekerk, A.A. 1990. Textuality and the human sciences: an appraisal of Paul Ricoeur, Scriptura S5.

Van Niekerk, A.A. 2017. A department under siege: How philosophy at Stellenbosch was split to survive, Stellenbosch Theological Journal 3 (1):451-473.

West, G.O. 1990. Can a literary reading be a liberative reading? Scriptura 35:10-25. 